\title{
Colorectal hyperplasia and inflammation in keratin 8-deficient FVB/N mice
}

\author{
Hélène Baribault, ${ }^{1,4}$ Jocelyn Penner, ${ }^{2}$ Renato V. Iozzo, ${ }^{3}$ and Marcia Wilson-Heiner ${ }^{1}$ \\ ${ }^{1}$ La Jolla Cancer Research Foundation, La Jolla, California 92037 USA; ${ }^{2}$ University of Missouri, Columbia, Missouri \\ 65205 USA; ${ }^{3}$ Department of Pathology and Cell Biology, Thomas Jefferson University, Philadelphia, Pennsylvania \\ 19107 USA.
}

\begin{abstract}
We report that keratin $8(\mathrm{mK} 8)$ gene disruption causes colorectal hyperplasia in FVB/N mice. The intestinal lesions affect uniformly the cecum, colon, and rectum but not the small intestine. The elongation of the crypts is accompanied by an inflammation of the lamina propria and submucosa. Hepatic, renal, and pancreatic functions tested in clinical assays are within nonpathological range, suggesting that the major defect lies in colonic epithelial cells. Still, small but consistent elevation in the hepatic enzymes alanine (AST) and asparate (ALT) aminotransferase are observed, along with a $70 \%$ increase in spleen weight. No homozygous mouse line has been established, because of a markedly reduced fertility of the $m K 8^{-/}-$females. Previously, we reported that the $\mathrm{mK8}^{-}$targeted mutation causes embryonic lethality in $(\mathrm{C} 57 \mathrm{Bl} / 6 \times 129 \mathrm{~Sv}$ ) mice. This strong effect of the genetic background on the $\mathrm{mK8}^{-}$mutant phenotype emphasizes the importance of using several inbred mouse strains to reveal the polygenic contribution to mutant phenotypes. Our results demonstrate that genetic modifiers of K8/K18 filament functions, with profound effects on embryogenesis and gut functional integrity, are differentially active in the FVB/N and C57Bl/6 genetic backgrounds. More importantly, the increase in $\mathrm{mKr}^{-1-}$ gut epithelial cell number, rather than cell disruption, contrasts with the known function of epidermal keratins in providing mechanical strength.
\end{abstract}

[Key Words: Keratin 8; epithelium; gut; sterility; gene knockout; hyperplasia; ulcerative colitis]

Received August 10, 1994; revised version accepted October 28, 1994

As we learn more about the gene products responsible for genetic diseases, it becomes clear that numerous, if not most, of the inherited diseases are polygenic (Bell 1993). The importance of genetic modifier loci on the penetrance of mutant phenotypes in mammals is well documented (Donehower et al. 1992; Smithies 1993). A prominent example is the modifier of the multiple intestinal neoplasia (Min) mutation, Mom-1, which reduces the penetrance of multiple intestinal neoplasia from $50 \%$ to an almost complete absence of tumors in different mouse strains (Moser et al. 1992; Dietrich et al. 1993). Similarly, we reported previously that a keratin $8(m K 8)$ targeted mutation in mice causes embryonic lethality with an incomplete penetrance of $94 \%$. The majority of homozygous embryos died at mid-gestation. However a substantial heterogeneity in the stage of lethality was observed. In this study we tested the hypothesis that genetic modifiers of $\mathrm{mK} 8$ function could be differentially active in different mouse strains and, consequently, be responsible for the heterogeneity first observed in the $\mathrm{mK} 8^{-}$mouse line. We now report that such modifiers of $\mathrm{mK} 8$ function exist and that they are differentially active in the $\mathrm{C} 57 \mathrm{Bl} / 6$ and $\mathrm{FVB} / \mathrm{N}$ mouse strains.

Keratins belong to a multigene family, whose members are divided into two types: Keratin filaments are

${ }^{4}$ Corresponding author. obligate heteropolymers formed from at least one member of each type; type I and type II. Pairs of type II/type I keratin filaments are differentially expressed in various epithelial cells (Hatzfeld and Franke 1985; Steinert and Roop 1988). Most single-layered (simple) epithelia express the type II $\mathrm{mK} 8$ and its type I partner keratin 18 (mK18), either alone or along with $\mathrm{K} 7, \mathrm{~K} 19$, and $\mathrm{K} 20$ (Moll et al. 1982, 1993). Despite the expression of multiple keratin family members in simple epithelia, the $m K 8$ targeted mutation prevents the formation of extended keratin filaments in all tissues where $m K 8$ is the only type II keratin expressed, for example, in the trophectoderm, endoderm, gut, liver, uterus, and mammary gland lumen epithelium (Baribault et al. 1993). The availability of adult homozygous $m K 8^{-} \mathrm{FVB} / \mathrm{N}$ mice provides us with a genetic system to study the function of simple epithelium keratins in adult tissues. We report that $\mathrm{mK} 8$ plays a central role in the integrity of the gastrointestinal (GI) tract and, possibly, in the reproductive tract.

\section{Results}

Homozygous $\mathrm{mK} 8^{-1-} \mathrm{FVB} / \mathrm{N}$ progeny escape the $\mathrm{mK} 8^{-}$ embryonic lethality

Previously, we reported that targeted disruption of the $m K 8$ gene causes mid-gestational lethality, albeit 
with an incomplete penetrance (Baribault et al. 1993). Matings of heterozygous $\mathrm{mK} 8^{-1+}$ males and females from a $(\mathrm{C} 57 \mathrm{Bl} / 6 \times 129 \mathrm{~Sv})$ genetic background, results in $1.6 \pm 0.6 \%(7 / 442)$ of viable homozygous adult progeny. To test whether the genetic background of mice carrying the $m \mathrm{~K}^{-}$mutation could account for the heterogeneity of the reported mutant phenotype and be responsible for some homozygous embryos to escape embryonic lethality, we bred the $m \mathrm{~K}^{-1+}$ mice for several generations with three different mouse strains, C57Bl/6, 129J, and $\mathrm{FVB} / \mathrm{N}$, respectively. FVB/N is an inbred mouse strain used in several transgenic mouse laboratories because of its enlarged male pronucleus that facilitates DNA microinjection (Taketo et al. 1991). Heterozygous $m \mathrm{~K}^{-1+}$ female mice were bred to wild-type $\mathrm{FVB} / \mathrm{N}$ males, to ensure that all chromosomes, including the $\mathrm{Y}$ chromosome, would be represented in the resulting progeny. Some heterozygous progenies were bred further to pure FVB/N wild-type mice for subsequent backcrosses, and the remaining heterozygous males and females were mated to determine the penetrance of embryonic lethality after one backcross to $\mathrm{FVB} / \mathrm{N}$ mice. From this latter breeding, $9.1 \%$ of homozygous adult mice were obtained. Because $25 \%$ of homozygous mice would be expected from a standard Mendelian transmission, we calculated that $36.4 \%$ of all homozygous embryos had escaped embryonic lethality after one backcross to FVB/N
(Fig. 1A). This procedure was repeated sequentially for five backcrosses to $\mathrm{FVB} / \mathrm{N}$; that is, heterozygous males and females generated after two generations of matings to pure $\mathrm{FVB} / \mathrm{N}$ were bred, and $55 \%$ of all homozygous embryos escaped embryonic lethality after two backcrosses. This percentage did not increase further with subsequent backcrosses.

Similarly, heterozygous $\left.\mathrm{mK}^{-1+} \mid \mathrm{C} 57 \mathrm{Bl} / 6 \times 129 \mathrm{~Sv}\right)$ females were bred to $129 \mathrm{~J}$ males and the resulting heterozygous progeny were mated. After one backcross to 129J and subsequent heterozygote matings, only $1.0 \pm 1.0 \%$ $(1 / 103)$ of homozygous adult mice were observed. This percentage was not significantly different from $1.6 \%$ reported prior to matings with 129J, suggesting that in contrast with backcrosses to $\mathrm{FVB} / \mathrm{N}$, backcrosses to $129 \mathrm{~J}$ had little or no effect on the penetrance of $\mathrm{mK}^{-} \mathrm{em}-$ bryonic lethality.

These results demonstrate the presence of genetic modifiers of $m K 8$ function, differentially active in $(\mathrm{C} 57 \mathrm{Bl} / 6 \times 129 \mathrm{~Sv})$ and $\mathrm{FVB} / \mathrm{N}$ genetic backgrounds, that can affect the penetrance of $m \mathrm{~K}^{-}$embryonic lethality.

\section{Homozygous mK8 $8^{-1-}$ adult $F V B / N$ mice develop an inflammatory bowel disease with colorectal hyperplasia}

The first pathological symptom in $m K 8^{-1-} \mathrm{FVB} / \mathrm{N}$ mice
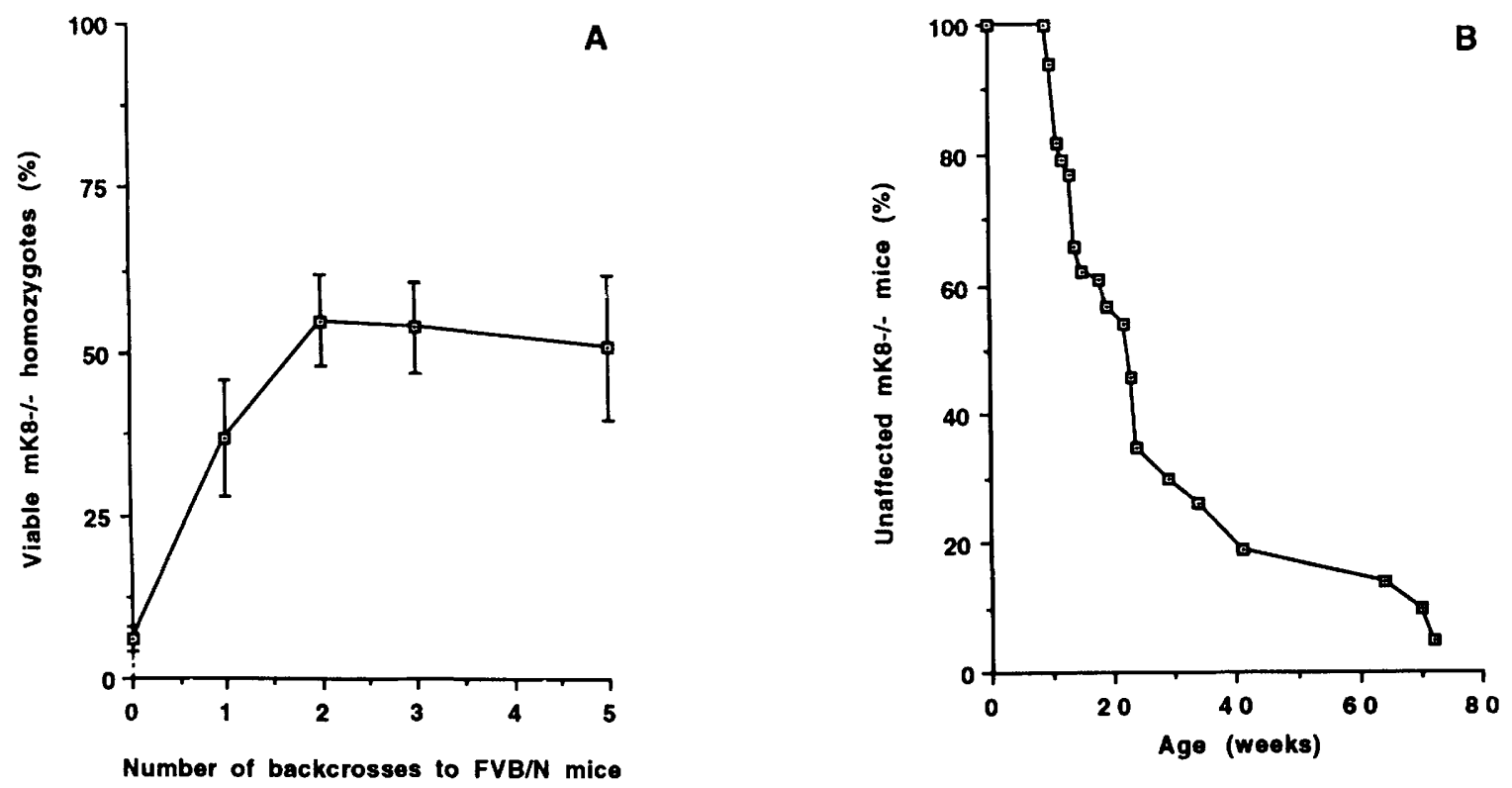

Figure 1. Penetrance of the $m K 8^{-1-}$ embryonic lethality $(A)$ and gastrointestinal disorder $(B)$ in $\mathrm{FVB} / \mathrm{N}$ mice. $(A) \mathrm{C} 57 \mathrm{Bl} / 6 \mathrm{females}$ carrying a $m K 8^{-}$targeted mutation were bred to pure $\mathrm{FVB} / \mathrm{N}$ males to ensure that all $\mathrm{FVB} / \mathrm{N}$ chromosomes, including $\mathrm{Y}$ chromosome, were represented in the offspring. From the progeny, male and female heterozygous siblings $\left(\mathrm{F}_{1}\right)$ were bred further to score the number of homozygous offspring (first backcross). This procedure was repeated sequentially for additional backcrosses, i.e., heterozygous $F_{1}$ offspring were bred to pure $\mathrm{FVB} / \mathrm{N}$ mice, the $\mathrm{F}_{2}$ heterozygous siblings were mated, and the number of resulting homozygous progeny was scored (second backcross). The percentage represented here reflects the percentage of postweaning homozygous offspring over the number of expected homozygous offspring from a Mendelian transmission. Between 140 and 450 individuals from heterozygote breeding were genotyped for each backcross. Error bars are standard deviations applied to a binomial distribution. $(B)$ Penetrance of the GI disorder. Affected mice were scored at the first observation of anorectal prolapse. The curve represents the percentage of nonaffected mice, relative to their age. Fifty percent of the mice were affected by the age of 5 months. By 12 months, $81 \%$ of 34 homozygous mice were affected by the GI disease. Both males and females were equally affected. 
was seen externally by the appearance of anorectal prolapse (Fig. 2A,B). Eighty-one percent of all homozygous adult mice developed this intestinal disorder between the age of 9 weeks and 1 year (Fig. 1B). An equal number of wild-type and heterozygous littermates were kept as controls. No wild-type mouse suffered from intestinal disorders. Only $3 \%(1 / 30)$ of heterozygotes suffered from the anorectal prolapse. Because this was a single event, it is not clear yet whether this reflects a dose effect of the $m K 8^{-}$mutation or whether the nontargeted allele was spontaneously mutated. Interestingly, from the six escapees obtained previously in a C57Bl $6 \times 129$ Sv genetic background and kept $>16$ months, none suffered from an anorectal prolapse. This suggests that FVB/N mice have a higher susceptibility to the $m K 8^{-}$bowel disease and that genetic modifiers of $m K 8$ functions not only can affect embryogenesis but also adult tissues.

In 6-week-old unaffected mutants, the intestine was indistinguishable from their wild-type or heterozygous counterpart (data not shown). Two days after the onset of the GI tract disorder, macroscopic examination of the GI tract of $m \mathrm{~K}^{-1-}$ mice showed a hyperplasic lesion restricted to the posterior part of the colon and the rectum. After 7 days, the lesion progressed to affect homogeneously the whole colon from the ileocaecal junction to the anus, but not the small intestine (Fig. 2C). This sug-
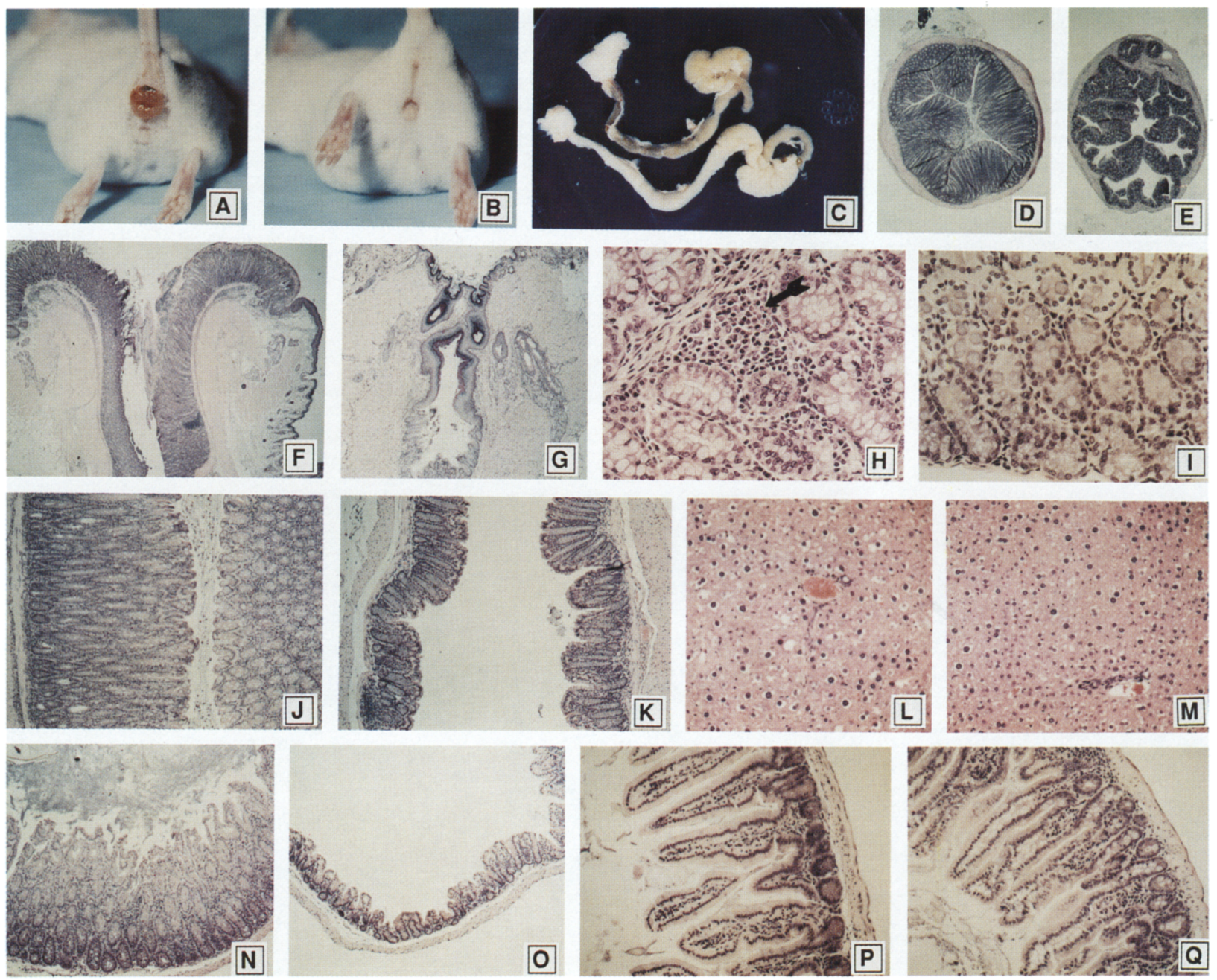

Figure 2. Anatomic and histological analysis illustrating the anorectal prolapse and colorectal hyperplasia in $m K 8^{-} \mathrm{FVB} / \mathrm{N}$ mutants. (A) A severe anorectal prolapse in a typical homozygous $m K 8^{-} \mathrm{FVB} / \mathrm{N}$ mouse compared with a control mouse $\langle B|$, respectively. In $C$, the homozygous animal (bottom) exhibits a hyperplasia of the gut extending from the anus to the ileocaecal junction; (top) control; (bottom) homozygote. (D-Q) Hematoxylin-eosin staining of paraffin sections from $m K 8^{-} \mathrm{FVB} / \mathrm{N}$ mutants $(D, F, H, J, L, N, P)$ and control $\{E, G, I, K, M, O, Q)$ tissues. $(D, E)$ Low-power magnification $(17.5 \times)$ of proximal colon cross sections. $(F, G)$ Lateral sections of the anorectal areas. Note that because of a significant size difference, the mutant anorectal canal is presented at a lower magnification $(17.5 \times)$ than the control $(35 \times) .(H, I)$ High-power magnification $(280 \times)$ of the colon. Note the presence of inflammation in the submucosa and lamina propria in the mutant colon (arrow). $(J, K)$ Low-power magnification of the colon $(35 \times)$. Note the elongated crypts (approximately fivefold) in the mutant colon and the marked reduction of the lumen diameter. $(L, M)$ Liver $(140 \times) .(N, O) C e c u m$ $(35 \times)$. Note the thickening of the mutant cecal epithelium. $(P, Q)$ Jejunum $(140 \times)$. 
gests that $\mathrm{mK} 8$ is required for large bowel homeostasis but is not necessary for the function of the small bowel. Longitudinal dissection of the GI tract from the esophagus to the rectum revealed no focal neoplasic growth. Feces were watery in contrast to bead-like stool in control mice.

Histological analysis of the affected lesions revealed a hyperplasia of the cecum, colon, and the anorectal area (Fig. 2F,G,J,K,N,O). The villi in all three tissues were elongated from 5 to 10 -fold. Despite an increase in gut epithelial cell number, the crypt cells underwent normal maturation along the villi, and a normal proportion of mucin-producing goblet cells was observed. No abnormal branching of the villi or ulceration was observed. An inflammation of the submucosa and the lamina propria was seen in mice sacrificed 7 days after the onset of the disease (Fig. $2 \mathrm{H}, \mathrm{I}$ ) but not in mice sacrificed 2 days after the first observation of the anorectal prolapse. These results suggest that the inflammatory component of the $\mathrm{mK} 8^{-}$bowel disease is secondary to the colorectal hyperplasia. A simple explanation could be that the epithelial hyperplasia increased friction and thus caused local microscopic disruption of enterocyte adhesion, thereby altering the immune barrier function of the epithelium and stimulating an immune response. No significant histological difference was seen in the small intestine of mutant and control mice (Fig. 2P,Q). A small splenomegaly was the only consistent finding in other organs (Table 1), but no histological abnormalities were observed in the bone marrow and spleen (data not shown).

We excluded the possibility that the anorectal prolapse was the result of a pathogenic microorganism infection for the following reasons. First, the $m K 8$ colony is maintained in a specific pathogen-free (SPF) animal facility. Sentinel mice are analyzed monthly to confirm the absence of known pathogenic microorganisms. Homozygous and control $\mathrm{mK}^{-}$mice were also subjected to the same tests. Second, affected mutants and nonaffected control mice are housed in the same cages. Consequently, if an undetected microorganism was responsible for this phenotype, it would be pathogenic to homozygous mice only. However, we cannot exclude that the presence of an undetected microorganism would be a cofactor to the phenotype.

Histological analysis of the lung, kidney, pancreas, stomach, heart, and brain in mutant and control mice revealed no abnormalities (data not shown). No liver lesions were observable in mice sacrificed 1 week after the first observation of anorectal prolapse (Fig. $2 \mathrm{~L}, \mathrm{M}$ ). However, coagulative liver necrosis and pericholangial fibrosis associated with lymphocytic infiltrates were observed in two of four mice sacrificed at a later stage, that is, 3 weeks after the observation of the anorectal prolapse. Although these lesions are often characteristic of degenerative aging changes in mice older than 1 year, they were observed in 3-month-old homozygous $\mathrm{mK}^{-}$ mice. Moreover, age- and sex-matched control littermates did not display similar liver pathologies.

To reveal whether the functional activities of organs normally expressing $m K 8$ were altered, a full serum chemistry profile of $m \mathrm{~K}^{-1-}$ and control mice were performed (Table 1). Levels of serum albumin from the $m \mathrm{~K}^{-1-}$ mice were indistinguishable from control mice. Small but consistent elevation of alanine (ALT) and asparate (AST) aminotransferase was observed. A 10fold elevation in seric AST and ALT is frequently associated with liver cirrhosis, because of the release of these enzymes by necrotic hepatocytes. However, the two- to threefold elevation observed here, while statistically significant, was within normal range. It could still reflect an increased susceptibility to liver injury. Levels of serum electrolytes, cholesterol, blood urea nitrogen, glucose, and bilirubin were not affected significantly by the $m K 8^{-}$mutation, indicating that at least some renal, pancreatic, muscle, and parathyroid hormone functions were normal. A small, but consistent, $50 \%$ decrease in the level of alkaline phosphatase was also observed, although this low level was still within normal range.

The hematology profile of mutant and control mice revealed no anemia or increase in white blood cells (Table 1). This is a further indication that the colorectal inflammation in mutant mice does not result from an infectious agent.

\section{Homozygous $\mathrm{mK} 8^{-1-}$ females are sterile}

Although the majority of $m K 8^{-1-} \mathrm{FVB} / \mathrm{N}$ mice survive into adulthood, no homozygous line could be established. $m K 8^{-1-}$ male fertility is indistinguishable from fertility in their control littermates (Table 2). $m K 8^{-1-}$ females from both genetic backgrounds have a markedly reduced fertility, despite their ability to produce fertilized eggs, and decidual response (data not shown). These results show that in addition to the GI tract, the reproductive tract is affected in $m \mathrm{~K}^{-1-}$ females.

\section{Status of simple epithelium keratins in $\mathrm{mK} 8^{-1-}$ mice}

To determine the status of simple epithelium keratins in $m \mathrm{~K}^{-1-}$ mice, we stained the small (Fig. 3) and large (Fig. 4) intestine, the liver (Fig. 5) and the lung (Fig. 6) by immunofluorescence with anti-mK $7,-\mathrm{mK} 8,-\mathrm{mK} 18$, $-\mathrm{mK} 19$ and $-\mathrm{mK} 20$ antibodies. For clarity, these results are also summarized in Table 3 . We have confirmed that $\mathrm{mK} 8$ was undetectable by immunofluorescence in all $m K 8^{-1-}$ tissues analyzed from the $\mathrm{FVB} / \mathrm{N}$ mouse strain , as reported previously for the $\mathrm{C} 57 \mathrm{Bl} / 6$ tissues. In the absence of $\mathrm{mK} 8$, the partners, $\mathrm{mK} 18$ and $\mathrm{mK} 19$, are unable to form extended filaments. They are either undetectable by immunofluorescence in hepatocytes (Fig. 5) or residual $\mathrm{mK} 18$ and $\mathrm{mK} 19$ aggregates are observed in proximity of the cell surface, in the small and large intestine (Figs. 3 and 4). Because keratins are obligate heteropolymers, we assessed the presence of type II $\mathrm{mK} 7$ in tissues where residual type $\mathrm{I} \mathrm{mK} 18$ and $\mathrm{mK} 19$ were observed. Low but detectable levels of anti-mK7 staining was observed in the small and large intestine. The monoclonal antibody RCK-105 (anti-mK7), generated against human $\mathrm{K} 7$, is known to be absent in the human intestine (Ramaekers et al. 1987). Its specificity in mouse tissues 
Table 1. Serum chemistry and hematology profile of homozygous $\mathrm{mK} 8^{-1}$ and control FVB/N mice

\begin{tabular}{|c|c|c|c|c|c|c|c|c|}
\hline & \multirow[b]{2}{*}{ Units } & \multirow{2}{*}{$\begin{array}{l}\text { Unaffected } \\
\text { homozygote }\end{array}$} & \multirow{2}{*}{$\begin{array}{l}\text { Littermate } \\
\text { control }\end{array}$} & \multirow{2}{*}{$\begin{array}{l}\text { Affected } \\
\text { homozygote }\end{array}$} & \multirow{2}{*}{$\begin{array}{l}\text { Littermate } \\
\text { control }\end{array}$} & \multicolumn{2}{|c|}{$\begin{array}{c}\text { Ratio } \\
\text { (homozygote/control) }\end{array}$} & \multirow{2}{*}{$\begin{array}{l}\text { Significant } \\
\text { difference }\end{array}$} \\
\hline & & & & & & unaffected & affected & \\
\hline \multicolumn{9}{|l|}{ Chemistry } \\
\hline glucose & $\mathrm{mg} / \mathrm{dl}$ & 228 & 332 & 150 & 182 & 0.69 & 0.83 & no \\
\hline BUN & $\mathrm{mg} / \mathrm{dl}$ & 24 & 21 & 25 & 23 & 1.14 & 1.11 & no \\
\hline creatinine & $\mathrm{mg} / \mathrm{dl}$ & 0.2 & 0.2 & 0.2 & 0.2 & 1.00 & 1.14 & no \\
\hline total protein & grams/dl & 4.9 & 5.2 & 4.1 & 4.6 & 0.94 & 0.89 & no \\
\hline albumin & grams/dl & 2.3 & 2.9 & 1.9 & 2.3 & 0.79 & 0.83 & no \\
\hline globulin & grams/dl & 2.6 & 2.5 & 2.2 & 2.3 & 1.04 & 0.96 & no \\
\hline sodium & mmole/liter & 177 & 172 & 158 & 159 & 1.03 & 0.99 & no \\
\hline potassium & mmole/liter & 6.0 & 4.1 & 4.9 & 4.7 & 1.46 & 1.04 & no \\
\hline chloride & mmole/liter & 135 & 127 & 123 & 123 & 1.06 & 1.00 & no \\
\hline calcium & $\mathrm{mg} / \mathrm{dl}$ & 9.9 & 10.0 & 7.6 & 7.8 & 0.99 & 0.98 & no \\
\hline phosphorus & $\mathrm{mg} / \mathrm{dl}$ & 12.1 & 8.7 & 10.6 & 8.7 & 1.39 & 1.21 & no \\
\hline bilinubin, total & $\mathrm{mg} / \mathrm{dl}$ & 0 & 0 & 0.2 & 0.6 & no difference & 0.32 & no \\
\hline ALT & U/liter & 285 & 92 & 149 & 37 & 3.10 & 4.04 & yes \\
\hline $\begin{array}{l}\text { AST } \\
\text { alkaline }\end{array}$ & U/liter & 289 & 115 & 386 & 152 & 2.52 & 2.54 & yes \\
\hline phosphatase & U/liter & 150 & 261 & 43 & 81 & 0.58 & 0.53 & yes \\
\hline cholesterol & U/liter & 77 & 97 & 75 & 98 & 0.79 & 0.76 & no \\
\hline \multicolumn{9}{|l|}{ Hematology } \\
\hline WBC & $\times 10 \mathrm{E} 3$ & 6.3 & 5.3 & 6.6 & 3.3 & 1.19 & 2.01 & no \\
\hline RBC & $\times 10 \mathrm{E} 6$ & 8.8 & 9.6 & 6.0 & 7.5 & 0.91 & 0.80 & no \\
\hline hemoglobin & grams/dI & 14.6 & 15.2 & 11.0 & 12.4 & 0.96 & 0.88 & no \\
\hline hematocrit & $\%$ & 43.0 & 44.6 & 30.0 & 33.2 & 0.96 & 0.90 & no \\
\hline MCV & $\mu \mathrm{m}^{3}$ & 49.1 & 46.6 & 49.6 & 44.2 & 1.05 & 1.12 & no \\
\hline $\mathrm{MCH}$ & pg & 16.7 & 15.9 & 18.2 & 16.6 & 1.05 & 1.10 & no \\
\hline $\mathrm{MCHC}$ & $\%$ & 34.0 & 34.1 & 36.8 & 37.5 & 1.00 & 0.98 & no \\
\hline \multicolumn{9}{|l|}{ Hematology (differential) } \\
\hline neutrophil segment & $\%$ & 12 & 17 & 11 & 10 & 0.71 & 1.05 & no \\
\hline lymphocyte & $\%$ & 80 & 79 & 88 & 88 & 1.01 & 1.00 & no \\
\hline monocyte & $\%$ & 4 & 1 & 1 & 1 & 4.00 & 1.50 & no \\
\hline eosinophil & $\%$ & 4 & 3 & 1 & 2 & 1.33 & 0.63 & no \\
\hline basophil & $\%$ & 0 & 0 & 0 & 0 & no difference & no difference & no \\
\hline platelets estimate & & adequate & adequate & adequate & adequate & N.A. & N.A. & no \\
\hline \multicolumn{9}{|l|}{ Others } \\
\hline spleen weight & mg & 168 & 126 & 193 & 113 & 1.33 & 1.70 & yes \\
\hline
\end{tabular}

Approximately $800 \mu \mathrm{l}$ of blood from nine pairs of homozygous and control littermates was obtained by cardiac puncture and analyzed in detail. To monitor changes during the progression of the disease, two 6-week-old unaffected homozygous mice, and seven affected older $m K 8^{-1-}$ mutants (from 2.5 to 5 months), along with respective littermates, were analyzed. (N.A.) Not applicable; (BUN) blood urea nitrogen; (ALT) alanine aminotransferase; (AST) aspartate aminotransferase; (WBC) white blood cells; $(\mathrm{RBC})$ red blood cells; (MCV) mean corpuscular volume; (MCH) mean corpuscular hemoglobin; $(\mathrm{MCHC})$ mean corpuscular hemoglobin concentration. The significant difference refers to values that were consistently elevated or consistently decreased in the homozygotes for all pairs of littermates analyzed. In addition, the ratio (homozygote/control) was statistically different from 1 ( $\alpha<0.05$ ). However, the values were all within normal range for $\mathrm{FVB} / \mathrm{N}$ and $\mathrm{C} 57 \mathrm{Bl} / 6$ mice of comparable age.

has not yet been fully determined. There is a discrepancy between the staining pattern of RCK-105 in mouse and human intestine. This is possibly because of an interspecies difference in $\mathrm{K} 7$ expression pattern. Alternatively, RCK-105 might recognize a previously unidentified, but closely related, type II keratin in mice. RCK-105 antibodies stained the lung tissue and was absent from hepatocytes (Fig. 5) in control and $m K 8^{-1-}$ mutant mice as expected (Fig. 6).

Although anti-mK7 staining was observed in the intestine, it remains unlikely that $\mathrm{mK} 7$ is responsible for the differential phenotype observed between the FVB/N and $\mathrm{C} 57 \mathrm{Bl} / 6$ background. $\mathrm{mK} 7$ was undetectable in $\mathrm{mK} 8^{-1-}$ hepatocytes. Moreover, in the small and large intestine, $\mathrm{mK} 7$ staining was restricted to small aggregates near the cell surface, in both control and $m \mathrm{~K}^{-1-}$ mice. Still, the presence of $\mathrm{mK} 7$ explains the residual presence of $\mathrm{mK} 18$ and $\mathrm{mK} 19$ in gut tissues.

In contrast, anti-mK20 staining was undetectable by immunofluorescence in the small and large intestine. This suggests that preferential pairing between $\mathrm{mK} 8$ and $\mathrm{mK} 20$ normally occurs and that in the absence of $\mathrm{mK} 8$, $\mathrm{mK} 20$ does not pair with an alternative type II keratin.

\section{Discussion}

\section{Genetic modifiers of simple epithelium keratin} functions

We demonstrated that genetic modifiers of $\mathrm{mK} 8$ functions, with profound effects on embryogenesis and gut functional integrity, are differentially active in different 
Table 2. Fertility of $\mathrm{mK} 8^{-1-}$ females and males

\begin{tabular}{|c|c|c|c|c|c|c|c|}
\hline \multirow[b]{2}{*}{ Strain } & \multirow[b]{2}{*}{ Female } & & \multirow[b]{2}{*}{ Male } & \multirow[b]{2}{*}{ Pups/litter } & \multirow[b]{2}{*}{ Litters/female } & \multicolumn{2}{|c|}{ Fertile females } \\
\hline & & & & & & number & percent \\
\hline $\mathrm{C} 57 \mathrm{Bl} / 6$ & $+1+$ & $x$ & $-1+$ & 7.2 & 1.6 & $15 / 17$ & 88 \\
\hline $\mathrm{C} 57 \mathrm{Bl} / 6$ & $+1+$ & $x$ & $-1-$ & 8.0 & 1.3 & $10 / 14$ & 71 \\
\hline $\mathrm{C} 57 \mathrm{Bl} / 6$ & $-1+$ & $x$ & $-1-$ & 4.2 & 1.0 & $5 / 9$ & 56 \\
\hline $\mathrm{C} 57 \mathrm{Bl} / 6$ & $-1-$ & $x$ & $+1+$ & 2 dead pups at birth from 1 female & - & $0 / 2$ & 0 \\
\hline $\mathrm{C} 57 \mathrm{Bl} / 6$ & $-1-$ & $x$ & $-1-$ & spontaneous abortion & - & $0 / 1$ & 0 \\
\hline $\mathrm{FVB} / \mathrm{N}$ & $-1+$ & $x$ & $-1+$ & 7.8 & 2.0 & $18 / 19$ & 95 \\
\hline $\mathrm{FVB} / \mathrm{N}$ & $+1+$ & $x$ & $-1-$ & 8.9 & 1.6 & $7 / 9$ & 78 \\
\hline FVB/N & $-1+$ & $x$ & $-1-$ & one spontaneous abortion & - & $0 / 3$ & 0 \\
\hline $\mathrm{FVB} / \mathrm{N}$ & $-1-$ & $x$ & $+1+$ & 2 dead pups at birth from 1 female & - & $0 / 8$ & 0 \\
\hline $\mathrm{FVB} / \mathrm{N}$ & $-1-$ & $x$ & $-1+$ & 3/one litter & 1.0 & $1 / 2$ & 50 \\
\hline FVB/N & $-1-$ & $x$ & $-1-$ & 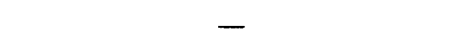 & - & $0 / 3$ & 0 \\
\hline Total: homozygous females & & & & & & $1 / 16$ & 6 \\
\hline
\end{tabular}

Homozygous and control males and females were bred to wild-type, heterozygous, or homozygous mice to test their reproductive abilities. Homozygous females of both $\mathrm{C} 57 \mathrm{Bl} / 6$ and $\mathrm{C} 57 \mathrm{Bl} / 6 \times \mathrm{FVB} / \mathrm{N} / \mathrm{FVB} / \mathrm{N})$ had a markedly reduced fertility.

mouse strains. Homozygous $m K 8^{-1-}$ adult FVB/N mice have a higher susceptibility to develop gut hyperplasia than their $\mathrm{C} 57 \mathrm{Bl} / 6 \times 129 \mathrm{~Sv}$ counterpart. Moreover, $m K 8$ genetic modifiers can rescue partially, but not entirely, $\mathrm{mK} 8$ functions, as different but severe phenotypes were observed in all genetic backgrounds.

The molecular nature of these genetic modifiers is unknown at present. Because very little is known about the molecular interaction of simple epithelium keratins with associated proteins and their significance, it is even premature to speculate on whether these genetic modifiers are structural or nonstructural gene products. More will need to be known about the chromosomal localization of these modifiers, and potentially more $\mathrm{K} 8 / \mathrm{K} 18$ associated proteins will need to be identified before we understand fully $\mathrm{mK} 8$ function(s) at the molecular level.

The $\mathrm{mK} 8^{-}$mouse line, maintained in a pathogen-free environment, shares some similarities to human inflammatory bowel diseases

Inflammatory bowel diseases (IBD) in humans, such as Crohn's disease or enterocolitis, and ulcerative colitis, are of unknown etiology. Recently, IBD with some similarities to human IBD pathologies have been reported in interleukin-2 (IL-2), IL-10, and T-cell receptor $\alpha$ (TCR $\alpha$ ) knockout mice (Kühn et al. 1993; Mombaerts et al. 1993; Sadlack et al. 1993). Both the onset and the histopathol-
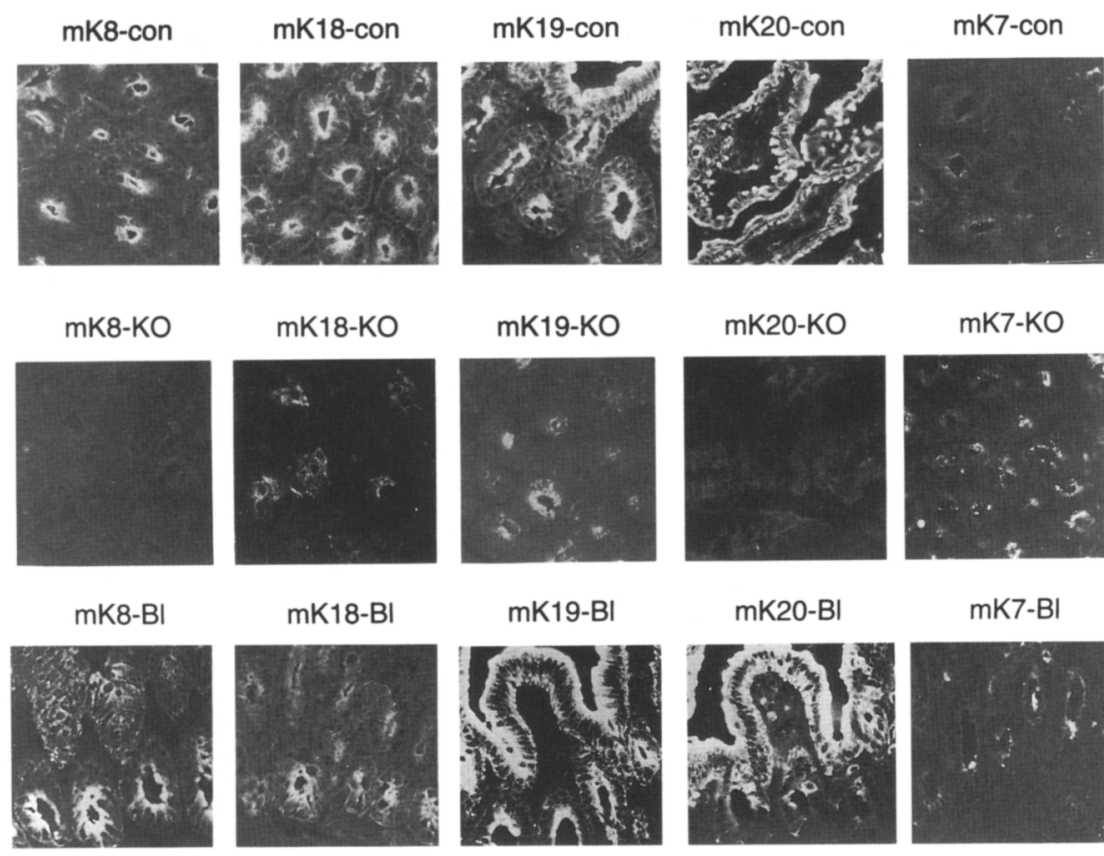
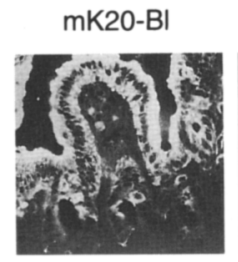

$\mathrm{mK} 7-\mathrm{KO}$

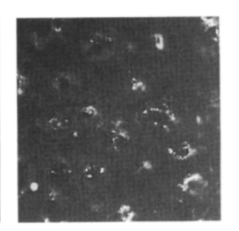

$\mathrm{mK} 7-\mathrm{Bl}$

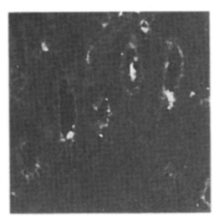

Figure 3. Immunofluorescence staining of the small intestine with anti-mK7, -mK8, $-\mathrm{mK} 18,-\mathrm{mK} 19$ and $-\mathrm{mK} 20$ antibodies. The respective antibody used is indicated at the top of each panel. (con) Control FVB/N tissues; (KO) $\mathrm{mK}^{-1-}$ homozygous tissues; (Bl) C57Bl/6 wild-type tissues. The magnification for all panels is $128 \times$. 
Figure 4. Immunofluorescence staining of the colon with anti-mK7,-mK8,-mK18, $-\mathrm{mK} 19$ and $-\mathrm{mK} 20$ antibodies. The panels are labeled as in Fig. 3. The magnification for all panels is $133 \times$.
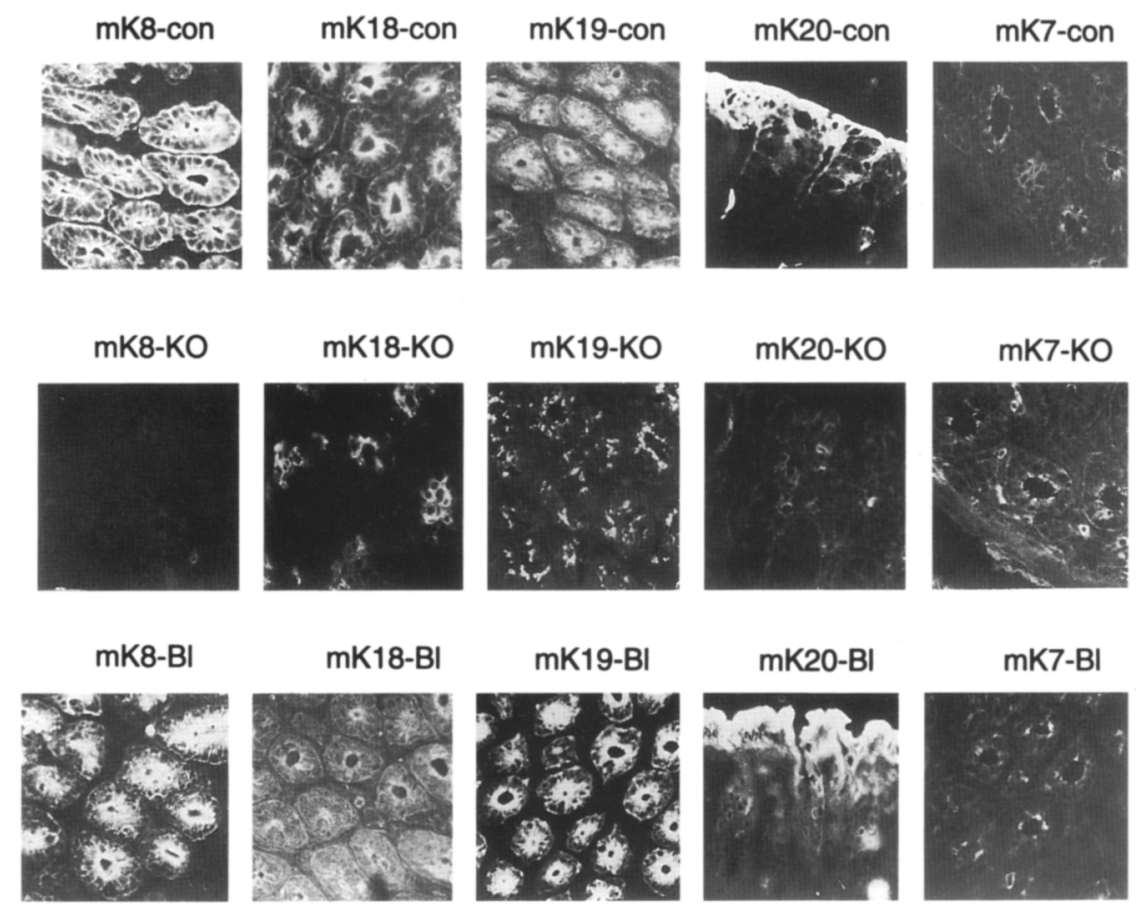

ogy of the $m \mathrm{~K}^{-}$IBD resemble the TCR $\alpha$ phenotype most closely, although some differences were also apparent. In both cases, the lesions do not involve the small intestine, no ulceration was observable, crypts were elongated, and inflammation occurred in the lamina propria and submucosa. However, no depletion of the mucin-producing goblet cells was observed in $\mathrm{mK}^{-1-} \mathrm{mu}$ tant mice, in contrast with a marked depletion in the TCR $\alpha$ mutants. These studies raised an important question: What is the contribution of pathogens as cofactors in the penetrance and severity of IBD? For example, lesion of the small intestine was found to be specific to a non-SPF environment, in IL-10 mutants. Because, the $m K 8^{-}$mouse colony has been maintained in a SPF environment only, it remains to be tested whether the $\mathrm{mK8^{- }}$ intestinal lesion would include the small intestine under non-SPF conditions. Because humans are exposed to several potential pathogens in their lifetime, a controlled introduction of pathogens in mutant mouse colonies will likely be useful in designing mouse models for human diseases.

Hepatobiliary disorders are observed frequently in human patients affected by IBD (White and Peters 1992). Fatty livers, pericholangitis, small elevation in ALT and AST, and portal vein hypertension resulting in splenomegaly have been associated with a significant number of IBD cases. Because most of these symptoms are observed in the $m \mathrm{~K}^{-}$mutant mice, future studies will focus on the potential interaction of liver functions with the development of $\mathrm{mK}^{-} \mathrm{IBD}$.

Simple epithelium vs. epidermal keratin functions: more than mechanical strength?

At the cellular level, the abnormal increase in gut epi- thelial cell number reported here is diametrically opposite to the keratinocyte disruption cellular phenotype found in mice expressing a dominant-negative skin ker-
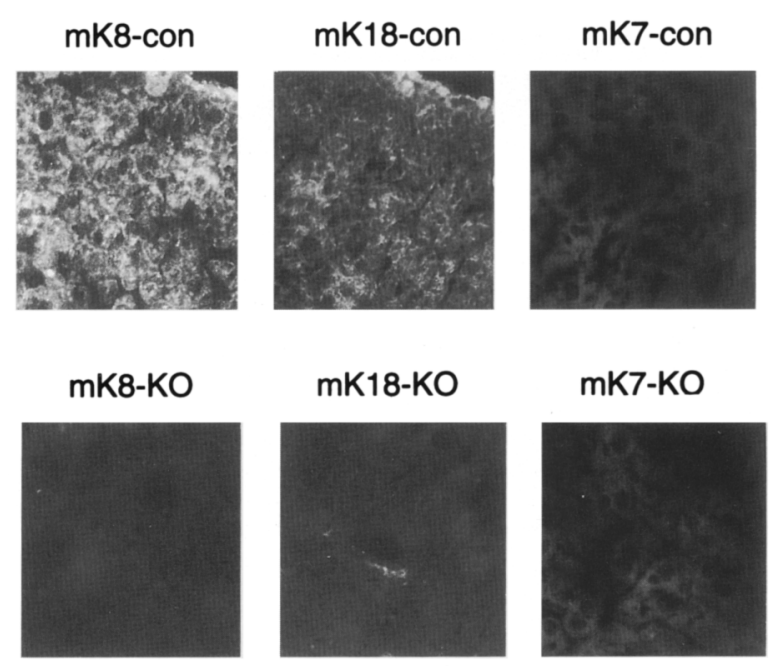

$\mathrm{mK} 8-\mathrm{BI}$

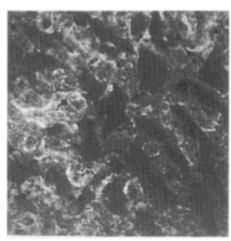

mK18-BI

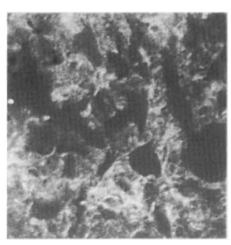

$\mathrm{mK} 7-\mathrm{BI}$

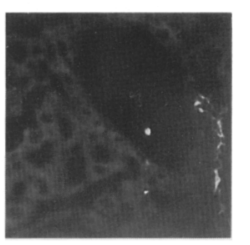

Figure 5. Immunofluorescence staining of the liver with anti$\mathrm{mK} 7,-\mathrm{mK} 8$, and $-\mathrm{mK} 18$ antibodies. The panels are labeled as in Fig. 3. The magnification for all panels is $133 \times$.

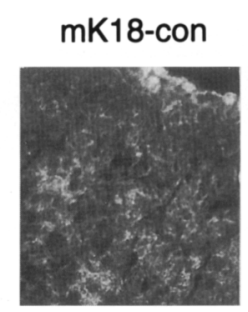


mK8-con

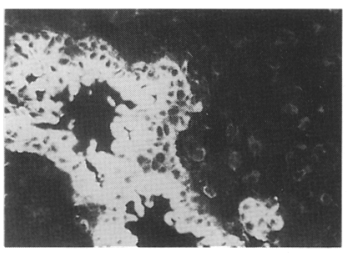

mK7-con

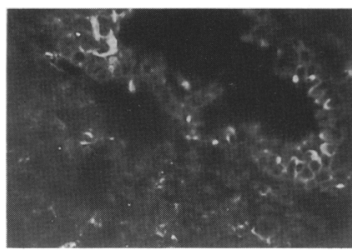

$\mathrm{mK} 8-\mathrm{KO}$

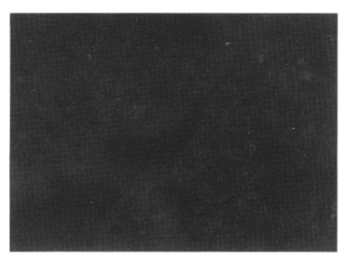

$\mathrm{mK} 7-\mathrm{KO}$

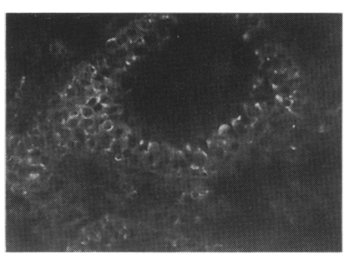

Figure 6. Immunofluorescence staining of the lung with anti$\mathrm{mK} 7$ and $-\mathrm{mK} 8$ antibodies. The panels are labeled as in Fig. 3. The magnification for all panels is $175 \times$.

atin mutation (Vassar et al. 1991). Intermediate filaments are often regarded as structural proteins that provide cell strength. Because no disruption of gut epithelial cells was observed in $m K 8^{-1-}$ mice, these results suggest that simple epithelium keratins may fulfill additional functions besides the known structural function of epidermal keratins. This is consistent with the observation that little homology is found in the head and tail domains from stratified and simple epithelium keratins, and with the hypothesis that these domains are thought to provide functional specificity to different keratin family members. It is not yet known, whether the increase in cell number results from overproliferation or an increase in cell longevity. The turnover of colon epithelial cells is normally 3 days, a turnover much shorter than for any other epithelial cells, under normal conditions. A slight increase in cell longevity could potentially result in colorectal hyperplasia. Future studies will test whether an increase in DNA synthesis or a reduction in apoptosis following bromodeoxyuridine injection and $\gamma$-radiation (Clarke et al. 1994; Merritt et al. 1994), is observed in $\mathrm{mK} 8^{-1-}$ mice.

No simple epithelium keratin mutations have been reported in humans. In contrast, numerous point mutations in human skin keratins have been shown to cause inherited skin diseases, such as epidermolysis bullosa simplex (EBS), hyperkeratosis (EHK), and palmoplantar keratoderma (Bonifas et al. 1991; Coulombe et al. 1991; Cheng et al. 1992; Chipev et al. 1992; Fuchs and Coulombe 1992; Lane et al. 1992; Rothganel et al. 1992; Fuchs and Weber 1994; Reis et al. 1994; Torchard et al. 1994). Because K8 and K18 are embryonic keratins already expressed at the blastocyst stage, it was largely assumed that K8 mutations would lead to embryonic lethality and would not be found in familial kindreds. Interestingly, the EBS and EHK mutations occur preferentially in amino acid sequences identical among all intermediate filaments including $\mathrm{K} 8$ and $\mathrm{K} 18$, that is, on either side of the rod domain, at the boundary with the head or the tail domains. Based on our finding that a $m K 8^{-}$mutation is not necessarily embryonically lethal, the hypothesis that EBS-like mutations also occur in human simple epithelium keratins, and could affect gut functional integrity and/or fertility in women, is worth exploring.

\section{Material and methods}

Husbandry

The establishment of the $m \mathrm{~K}^{-}$mouse line has been reported previously (Baribault et al. 1993). Mice were maintained in a

Table 3. Status of simple epithelium keratins in $\mathrm{mK} 8^{-1-}$ and control mice

\begin{tabular}{|c|c|c|c|c|c|}
\hline & \multicolumn{2}{|c|}{ Type II } & \multicolumn{3}{|c|}{ Type I } \\
\hline & $\begin{array}{c}\mathrm{mK} 7 \\
(\mathrm{RCK} 105)\end{array}$ & $\begin{array}{c}\mathrm{mK} 8 \\
(\text { TROMA-1) }\end{array}$ & $\begin{array}{c}\text { mK18 } \\
\text { (TROMA-2) }\end{array}$ & $\begin{array}{c}\text { mK19 } \\
\text { (TROMA-3) }\end{array}$ & $\begin{array}{c}\mathrm{mK} 20 \\
(\mathrm{ltK})\end{array}$ \\
\hline \multicolumn{6}{|l|}{ C57B1/6 control } \\
\hline liver (hepatocytes) & - & $++t$ & +++ & - & - \\
\hline small intestine & $-1+$ & +++ & ++ & $+t+$ & $++t$ \\
\hline colon & $-1+$ & +++ & +++ & +++ & +++ \\
\hline lung & + & +++ & $++t$ & $++t$ & - \\
\hline \multicolumn{6}{|l|}{ FVB/N control } \\
\hline liver (hepatocytes) & - & +++ & +++ & - & - \\
\hline small intestine & $-1+$ & $+t+$ & ++ & +++ & ++ \\
\hline colon & $-1+$ & $++t$ & $++t$ & +++ & +++ \\
\hline lung & + & +++ & $+t+$ & +++ & - \\
\hline \multicolumn{6}{|l|}{$\mathrm{FVB} / \mathrm{N} m K 8^{-/-}$} \\
\hline liver (hepatocytes) & - & - & - & - & - \\
\hline small intestine & $-1+$ & - & $-1+$ & $-1+$ & +++ \\
\hline colon & $-1+$ & - & $-1+$ & $-1+$ & +++ \\
\hline lung & + & - & + & + & - \\
\hline
\end{tabular}

The staining pattern for all keratins analyzed is similar in both $\mathrm{FVB} / \mathrm{N}$ and $\mathrm{C} 57 \mathrm{Bl} / 6$ genetic backgrounds. 
SPF animal facility. Sentinel mice were analyzed monthly to confirm the absence of known pathogenic microorganisms. Homozygous and control $\mathrm{mK}^{-}$mice were also submitted to the same tests.

\section{Genotype determination}

The genotype of each mouse was determined either by Southern blot and/or polymerase chain reaction (PCR) analysis of mouse tail DNA. The protocol for Southern blot analysis was described previously (Baribault et al. 1993). PCR determination was done as follows. Approximately $2 \mathrm{~mm}$ of the tail tip was boiled in 100 $\mu \mathrm{l}$ of distilled water for $3 \mathrm{~min}$. Fifteen microliters of $10 \mathrm{mg} / \mathrm{ml}$ of proteinase $\mathrm{K}$ was added to the tail extract and incubated at $55^{\circ} \mathrm{C}$ for $5 \mathrm{hr}$. The DNA extract was boiled again for $3 \mathrm{~min}$, to inactivate the proteinase $\mathrm{K}$. Two microliters of the DNA extract were directly used in a $25 \mu \mathrm{l}$ PCR reaction, along with $1 \mu \mathrm{g}$ of single-stranded binding protein, (U.S. Biochemical, Cleveland, $\mathrm{OH}$ ) (Oshima 1992), 2.5 units of Taq DNA polymerase (GIBCO/ $\mathrm{BRL}$ ), $1 \times T a q$ reaction buffer (provided by the manufacturer, GIBCO/BRL), $2 \mathrm{mM} \mathrm{MgCl} 2,80 \mu \mathrm{M}$ of each dNTP, $100 \mathrm{ng}$ of o-neo-3 (CCT GTC ATC TCA CCT TGC TCC TGC Cl, and K8-PCR3 (CGG TTA GTC GGG AAG AGA GGG GTC) oligonucleotides. After five cycles of PCR, melting at $94^{\circ} \mathrm{C}$ for 45 sec, annealing at $70^{\circ} \mathrm{C}$ for $30 \mathrm{sec}$, synthesis at $72^{\circ} \mathrm{C}$ for $45 \mathrm{sec}$, and extension at $72^{\circ} \mathrm{C}$ for $3 \mathrm{~min}, 100 \mathrm{ng}$ of o-ea-18 oligonucleotide (TTG GGT TAG GCC CTG CCT CTA GTG TCT) was added. The PCR reaction was allowed to resume for an additional 35 cycles followed by $10 \mathrm{~min}$ extension at $72^{\circ} \mathrm{C}$. The PCR products were separated on a $1 \%$ agarose gel in $0.5 \times$ TBE buffer. The expected product from the targeted allele, from o-neo- 3 and $\mathrm{K} 8$-PCR3, is $800 \mathrm{bp}$, whereas the wild-type allele from o-ea-18 and K8-PCR3 leads to a 500-bp PCR product.

\section{Hematology and clinical chemistry}

Approximately $500 \mu \mathrm{l}$ of blood was collected by cardiac puncture from homozygous animals and their respective control littermates, and was transferred immediately to a heparinized tube. A full body profile, including hematology and clinical chemistry, was performed by the OCVS Diagnostic Laboratory at the University of California, San Diego (La Jolla, CA). Briefly, whole blood was processed on a hematology analyzer (SeronoBaker 9000). Differential white blood cell counts were determined manually on blood smears after Wright staining on 100 cells. For clinical chemistry, heparinized plasma was processed on a chemistry analyzer (Idexx-Vettest 8008), and an automated data analyzer determined the respective values by enzymatic (alkaline phosphatase, AST, ALT, creatinine) or colorimetric assays (others).

\section{Histological analysis}

Hematoxylin and eosin staining was performed according to standard histological procedures on sections of paraffin-embedded adult tissues.

\section{Immunofluorescence}

TROMA-1, TROMA-2, and TROMA-3 rat monoclonal antibodies have been shown to recognize $m K 8, m K 18$, and $m K 19$ respectively, and were a gift from Dr. R. Kemler (Freiburg, Germany). In some cases, rabbit anti-mK18 antisera, a gift from Dr. R.G. Oshima, were used (Baribault and Oshima 1991). The antimK20 mouse monoclonal antibodies were a gift from Dr. W.W Franke (Moll et al. 1993). The anti-mK7, RCK-105, mouse monoclonal antibodies were purchased from ICN Biochemicals. Results were confirmed later with RCK-105 antibodies generously provided by Dr. F. Ramaekers (Ramaekers et al. 1987). FITC-labeled rabbit mouse absorbed anti-rat immunoglobulin (Vector Laboratories), rabbit anti-mouse immunoglobulin (ICN Biochemicals), and goat anti-rabbit immunoglobulin (ICN Biochemicals) antibodies were used with the respective first antibodies.

To reduce the background inherent to staining adult mouse tissues with mouse monoclonal antibodies, several immunofluorescence staining protocols were compared. This was particularly relevant to the liver which contains a high level of endogenous mouse immunoglobulin. For staining involving mouse monoclonal antibodies, frozen sections were fixed in $100 \%$ acetone at $-20^{\circ} \mathrm{C}$ for $10 \mathrm{~min}$. The sections were air-dried, followed by an incubation with nonimmune rabbit serum diluted $1: 100$. For other antibodies, frozen sections were fixed in $100 \%$ methanol at $-20^{\circ} \mathrm{C}$ for $10 \mathrm{~min}$. Subsequent steps were identical for all antibodies. Sections were incubated with PBS containing $3 \%$ BSA for $30 \mathrm{~min}$ at room temperature. PBS-BSA was used for the dilution of all antibodies. The first antibodies were then used either undiluted (RCK-105, TROMA-1, TROMA-2, TROMA-3, anti-mK20) or at a dilution of 1:30 (anti-mK18), at room temperature for $1 \mathrm{hr}$. Sections were washed in PBS-BSA for $10 \mathrm{~min}$ and incubated with the respective second antibodies at a dilution of 1:50. Sections were washed further with PBS alone for $10 \mathrm{~min}$ and mounted with SlowFade (Molecular Probes, Eugene, OR) for microscopic observation.

\section{Acknowledgments}

This work was supported by the National Institutes of Health (NIH) and the Stern Foundation (H.B.), and NIH and the American Cancer Society (ACS) (R.V.I.). We thank J. Avis and M. Herrick for mouse husbandry; M. Hasham, D. Haynes, and $H$. Wilson (University of Missouri) for art and photography work; and H.S. Henkelmann at University of California, San Diego, Department of Diagnostics, for clinical chemistry. We are grateful to Drs. R.G. Oshima, P. Martin, D. Weigel, and J.S. Zhu for critical review of the manuscript.

The publication costs of this article were defrayed in part by payment of page charges. This article must therefore be hereby marked "advertisement" in accordance with 18 USC section 1734 solely to indicate this fact.

\section{References}

Baribault, H. and R.G. Oshima. 1991. Polarized and functional epithelia can form after the targeted inactivation of both mouse keratin 8 alleles. I. Cell. Biol. 115: 1675-1684.

Baribault, H., J. Price, K. Miyai, and R.G. Oshima. 1993. Midgestational lethality in mice lacking keratin 8. Genes \& Dev. 7: 1191-1202.

Bell, J.I. 1993. Polygenic disease. Curr. Opin. Genet. Dev. 3: 466-469.

Bonifas, J.M., A.L. Rothman, and E.H. Epstein Jr. 1991. Epidermolysis bullosa simplex: Evidence in two families for keratin gene abnormalities. Science 254: 1202-1205.

Cheng, J., A.J. Syder, Q.C. Yu, A. Letai, A.S. Paller, and E. Fuchs. 1992. The genetic basis of epidermolytic hyperkeratosis: A disorder of differentiation-specific epidermal keratin genes. Cell 70: 811-819.

Chipev, C., B.P. Korge, N. Markova, S.J. Bale, J.J. DiGiovanna, J.G. Compton, and P.M. Steinert. 1992. A leucine $\rightarrow$ proline mutation in the $\mathrm{Hl}$ subdomain of keratin 1 causes epider- 
molytic hyperkeratosis. Cell 70: 821-828.

Clarke, A.R., S. Gledhill, M.L. Hooper, C.C. Bird, and A.H. Wyllie. 1994. p53 dependence of early apoptotic and proliferative responses within the mouse intestinal epithelium following $\gamma$-irradiation. Oncogene 9: 1767-1773.

Coulombe, P.A., M.E. Hutton, A. Letai, A. Hebert, A.S. Paller, and E. Fuchs. 1991. Point mutations in human keratin 14 genes of epidermolysis bullosa simplex patients: Genetic and functional analyses. Cell 66: 1301-1311.

Dietrich, W.F., E.S. Lander, J.S. Smith, A.R. Moser, K.A. Gould, C. Luongo, N. Borenstein, and W. Dove. 1993. Genetic identification of Mom-1 a major modifier locus affecting mininduced intestinal neoplasia in the mouse. Cell 75: 631-639.

Donehower, L.A., M. Harvey, B.L. Slagle, M.J. McArthur, C.A. Montgomery Jr., J.S. Butel, and A. Bradley. 1992. Mice deficient for p53 are developmentally normal but susceptible to spontaneous tumours. Nature 356: 215-221.

Fuchs, E. and P.A. Coulombe. 1992. Of mice and men: Genetic skin diseases of keratin. Cell 69: 899-902.

Fuchs, E. and K. Weber. 1994. Intermediate filaments: Structure, dynamics, function and disease. Annu. Rev. Biochem. 63: 345-382.

Hatzfeld, M. and W.W. Franke. 1985. Pair formation and promiscuity of cytokeratins: Formation in vitro of heterotypic complexes and intermediate-sized filaments by homologous and heterologous recombinations of purified polypeptides. $J$. Cell. Biol. 101: 1826-1841.

Kühn, R., J. Löhler, D. Rennick, K. Rajewsky, and W. Müller. 1993. Interleukin-10-deficient mice develop chronic enterocolitis. Cell 75: 263-274.

Lane, E.B., E.L. Rugg, H. Navsaria, I.M. Leigh, A.H.M. Heagerty, A. Ishida-Yamamoto, and R.A.J. Eady. 1992. A mutation in the conserved helix termination peptide of keratin 5 in hereditary skin blistering. Nature 356: 244-246.

Merritt, A.J., C.S. Potten, C.J. Kemp, J.A. Hickman, A. Balmain, D.P. Lane, and P.A. Hall. 1994. The role of p53 in spontaneous and radiation-induced apoptosis in the gastrointestinal tract of normal and p53-deficient mice. Cancer Res. 54: 614 617.

Moll, R., W.W. Franke, D.L. Schiller, B. Geiger, and R. Krepler. 1982. The catalog of human cytokeratins: Patterns of expression in normal epithelia, tumors and cultured cells. Cell 31: 11-24.

Moll, R., R. Zimbelmann, M.D. Goldschmidt, M. Keith, J. Laufer, M. Kasper, P.J. Koch, and W.W. Franke. 1993. The human gene encoding cytokeratin-20 and its expression during fetal development and in gastrointestinal carcinomas. Differentiation 53: 75-93.

Mombaerts, P., E. Mizoguchi, M.J. Grusky, L.H. Glimcher, A.K. Bhan, and S. Tonegawa. 1993. Spontaneous development of inflammatory bowel disease in $\mathrm{T}$ cell receptor mutant mice. Cell 75: 275-282.

Moser, A.R., W.F. Dove, K.A. Roth, and J.I. Gordon. 1992. The min (multiple intestinal neoplasia) mutation: Its effect on gut epithelial cell differentiation and interaction with a modifier system. I. Cell Biol. 116: 1517-1526.

Oshima, R.G. 1992. Single strand DNA binding protein facilitates amplification of genomic sequences by PCR. BioTechniques 13: 188.

Ramaekers, F., A. Huijsmans, G. Schaart, O. Moesker, and P. Voojis. 1987. Tissue distribution of keratin 7 as monitored by a monoclonal antibody. Exp. Cell Res. 179: 235-249.

Reis, A., H.C. Hennies, L. Langbein, M. Digweed, D. Mischke, M. Drechsler, E. Schröck, B. Royer-Pokora, W.W. Franke, K. Sperling, and W. Küster. 1994. Keratin 9 gene mutations in epidermolytic palmoplantar keratoderma (EPPK). Nature
Genet. 6: 174-179.

Rothganel, J.A., A.M. Dominey, L.D. Dempsey, M.A. Longley, D.A. Greenhalgh, T.A. Gagne, T.A. Huber, M. Frenk, D. Hohl, and D.R. Roop. 1992. Mutations in the rod domains of keratins 1 and 10 in epidermolytic hyperkeratosis. Science 257: 1128-1130.

Sadlack, B., H. Merz, H. Schorle, A. Schimpl, A.C. Feller, and I. Horak. 1993. Ulcerative colitis-like disease in mice with a disrupted interleukin-2 gene. Cell 75: 253-261.

Smithies, O. 1993. Animal models of human genetic diseases. Trends Genet. 9: 112-116.

Steinert, P.M. and D.R. Roop. 1988. Molecular and cellular biology of intermediate filaments. Annu. Rev. Biochem. 57: 593-625.

Taketo, M., A.C. Schroeder, L.E. Mobraaten, K.B. Gunning, G. Hanten, R.R. Fox, T.H. Roderick, C.L. Stewart, F. Lilly, C.T. Hansen, and P.A. Overbeek. 1991. FVB/N: An inbred mouse strain preferable for transgenic analyses. Proc. Natl. Acad. Sci. 88: 2065-2069.

Torchard, D., C. Blanchet-Bardon, O. Serova, L. Langbein, S. Narod, N. Janin, A.F. Goguel, A. Bernheim, W.W. Franke, G.M. Lenoir, and J. Feunteun. 1994. Epidermolytic palmoplantar keratoderma cosegregates with a keratin 9 mutation in a pedigree with breast and ovarian cancer. Nature Genet. 6: 106-110.

Vassar, R., P.A. Coulombe, L. Degenstein, K. Albers, and E. Fuchs. 1991. Mutant keratin expression in transgenic mice causes marked abnormalities resembling a human genetic skin disease. Cell 64: 365-380.

White, H. and M. Peters. 1992. Hepatobiliary disorders in inflammatory bowel disease. In Inflammatory bowel disease (ed. R.P. MacDermott and W.F. Stenson), pp. 405-417. Elsevier Science Publishing Co., New York. 


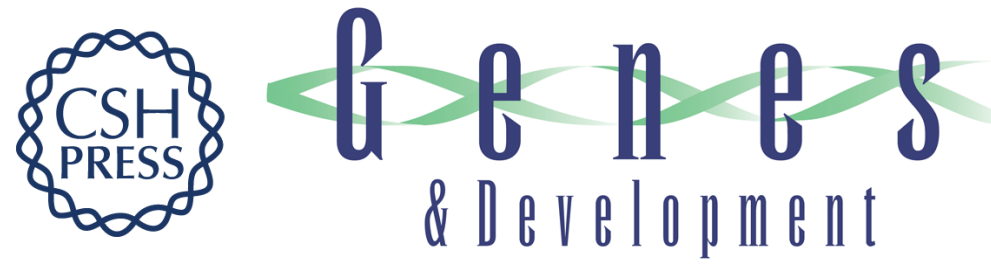

\section{Colorectal hyperplasia and inflammation in keratin 8-deficient FVB/N mice.}

H Baribault, J Penner, R V lozzo, et al.

Genes Dev. 1994, 8:

Access the most recent version at doi:10.1101/gad.8.24.2964

References This article cites 30 articles, 8 of which can be accessed free at:

http://genesdev.cshlp.org/content/8/24/2964.full.html\#ref-list-1

License

Email Alerting

Service

Receive free email alerts when new articles cite this article - sign up in the box at the top right corner of the article or click here.

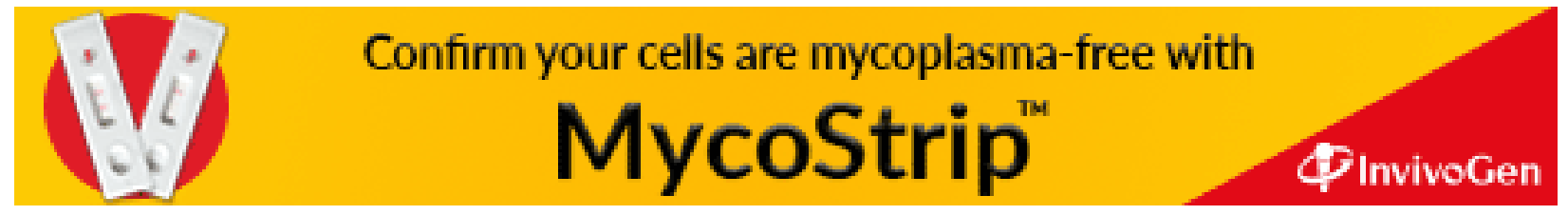

